\title{
当科における喉頭癌の動向
}

—特に臨床疫学面㧍よび喉頭温存率の面から—

$$
\begin{aligned}
& \text { 藤井隆, 佐藤 武男, 吉野 } \text { 邦俊 } \\
& \text { 稲上憲一, 長原昌萬, 沖田 純 }
\end{aligned}
$$

\section{Recent Trends in Treating Laryngeal Carcinoma : Some Observations on Clinical Epidemiological Status and Laryngeal Preservation Rate}

Takashi Fujii, M.D., Takeo Sato, M.D., Kunitoshi Yoshino, M.D., Ken-ichi Inakami, M.D., Masamitsu Nagahara, M.D., and Jun Okita, M.D. Department of Otolaryngology, Osaka Medical Center for Cancer and Cardiovascular Diseases, Osaka

A total of 1160 patients with previously untreated laryngeal carcinoma were registered in our hospital between 1979 and 1994. The mean age was 64 years (range : 22-91 years). These patients consisted of 746 cases of glottis, 393 supraglottis, 14 subglottis, and seven multicentric carcinomas. Some trends in their clinical epidemiological status and the laryngeal preservation rate were observed and compaired between the following two periods ; 1979-1986 and 1987-1994.

Our conclusions are listed below.

1) The age distribution was similar in both periods. Taking into account the increase in the ratio of early stages (stage I, II), however, it may be that there was a tendency toward older age.

2) The number of patients with glottic carcinoma increased from 356 to 390 , whereas, those with supraglottic carcinoma decreased from 200 to 193.

3) The laryngeal preservation rate in glottic carcinomas increased from $58 \%$ to $78 \%$, although the proportion of $\mathrm{T} 1$ to $\mathrm{T} 2$ cases showed an increase of only $7 \%$. The laryngeal preservation rate in $\mathrm{T} 1$ and $\mathrm{T} 2$ cases increased from $68 \%$ to $85 \%$. Similarly, the laryngeal preservation rate in supraglottic carcinoma increased from $10 \%$ to $27 \%$, although the proportion of $\mathrm{T} 1$ to $\mathrm{T} 2$ cases showed an increase of $11 \%$. The laryngeal preservation rate of $\mathrm{T} 1$ to $\mathrm{T} 2$ cases increased from $24 \%$ to $44 \%$. Consequently, it was suggested that the increase in the laryngeal preservation rate in cases of laryngeal carcinoma was dependent on not only an increase in the proportion of $\mathrm{T} 1$ to $\mathrm{T} 2$ cases, but also on an improvement in their diagnosis and treatment.

Key words : 喉頭癌，臨床統計，喉頭温存率，年次推移

大阪府立成人病センター耳鼻咽喉科

別刷請求：干537 大阪市東成区中道1-3-3 大阪府立成人病センター耳鼻咽喉科 藤井 隆

投稿受付：1997年 5 月21日

\section{I 、はじめに}

近年，癌患者の QOL が重視されるようにな り，特に喉頭癌のように予後のよい癌に対して は, 単に生存率だけではなく, 治療後の QOL が 
以前にもまして大きく評価されるようになって きている。いつぽう，社会に対する啓発運動(一 次・二次予防）の効果として, 早期癌患者の割 合が増加し, 機能温存が可能な症例数も増加し てきている。しかしながら，喉頭癌の年齢訂正

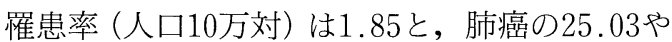
食道癌の 4.73 などに比較して低く ${ }^{1)}$ ，一施設で 扱う症例数が限られてくるため，年次推移に関 する臨床統計すら少なく ${ }^{2 \sim 4)}$, 喉頭温存率の推移 について検討したものはみられない。大阪府は 喉頭癌の高頻度府県で5)，年間罹患数は約 200 例1) であるが，当科では毎年70～80例の喉頭癌 患者の治療を行っている。当科に扔ける喉頭癌 の, 臨床からみた記述疫学・治療成績および喉 頭温存率の 16 年間の推移をまとめ考察した。

\section{II．対象および方法}

1979年から1994年までの16年間に登録された 喉頭癌一次例 1160 例を対象とした。根治治療は 1129例（根治治療施行率；97.3\%）に行われ， 17例に姑息治療が，14例は無治療で経過観察の みが行われていた。各年の症例数が70〜80例で, 年ごとの症例数に顕著な差がなかったため, 初 回治療法・T病期および喉頭温存率を比率で表 し，年次推移を概観した。また，臨床面からみ た記述疫学および喉頭温存率に関しては，16年 間を前期（1979〜 86年の 8 年間） 567例と後期 （1987～94年の 8 年間） 593例に分けて比較し, $\chi^{2}$ 検定を用いて検討した。

喉頭温存率は，1996年 5 月の調査時に，喉頭 が温存されていた生存例と, 喉頭が温存された 状態ですでに死亡していた症例を合わせた症例 数の占める比率とした。ただし，無治療例は， 全例喉頭が温存されたままの原病死であるた め，母数から除外した。治療開始からの経過観 察期間が 2 年未満の症例は 227 例 (生存 71 例；原 病死71例；他病死82例；不明 3 例)であったが, それ以外はすべて治療開始から 2 年以上経過し た時点の評価である。

\section{III. 結 果}

\section{1. 臨床面からみた記述疫学の推移}

喉頭癌罹患年齢の分布は，22～91歳（平均64 歳）で，60歳代が全体の35\%を占めていた。80
表 1 罹患年齢の推移

\begin{tabular}{lrrrr}
\hline $\begin{array}{l}\text { 罹患 } \\
\text { 年歯(歳) }\end{array}$ & $\begin{array}{c}\text { 前期 } \\
(1979 \sim 86 \text { 年 })\end{array}$ & $\begin{array}{c}\text { 後期 } \\
(1987 \sim 94\end{array}$ & \multicolumn{1}{c}{ 計 } \\
\hline$\sim 39$ & $3(0.5 \%)$ & $4(0.7 \%)$ & $7(0.6 \%)$ \\
$40 \sim 49$ & $22(3.9 \%)$ & $39(6.6 \%)$ & 61 & $(5.3 \%)$ \\
$50 \sim 59$ & $170(30.0 \%)$ & $156(26.3 \%)$ & $326(28.1 \%)$ \\
$60 \sim 69$ & $198(34.9 \%)$ & $213(35.9 \%)$ & $411(35.4 \%)$ \\
$70 \sim 79$ & $147(25.9 \%)$ & $141(23.8 \%)$ & $288(24.8 \%)$ \\
$80 \sim$ & $27(4.8 \%)$ & $40(6.7 \%)$ & $67(5.8 \%)$ \\
\hline 計 & $567(100 \%)$ & $593(100 \%)$ & 1160 & $(100 \%)$ \\
\hline
\end{tabular}

表 2 発癌部位の推移

\begin{tabular}{|c|c|c|c|}
\hline 発癌部位 & $\begin{array}{c}\text { 前期 } \\
(1979 \sim 86 \text { 年) }\end{array}$ & $\begin{array}{c}\text { 後期 } \\
\text { (1987〜 94年) }\end{array}$ & 計 \\
\hline 声 門癌 & $356(62.8 \%)$ & $390(65.8 \%)$ & 746 \\
\hline 声門上癌 & $200(35.3 \%)$ & $193(32.5 \%)$ & 393 \\
\hline (声門上型 & $144(25.4 \%)$ & $133(22.4 \%)$ & 277 \\
\hline 混 合 型 & $56 \quad(9.9 \%)$ & $60(10.1 \%)$ & 116 \\
\hline 声門下癌 & $(1.2 \%)$ & $7 \quad(1.2 \%)$ & 14 \\
\hline 多中心性 & $(0.7 \%)$ & $(0.5 \%)$ & 7 \\
\hline 計 & 567 & 593 & 1160 \\
\hline
\end{tabular}

歳以上が $5.8 \%, 70$ 歳以上が $30.6 \%$ 占めていた が，50歳未満は $5.9 \%$ に過ぎなかった。罹患年齢 の分布は, 前期と後期ではほぼ等しかったが, 80 歳以上の比率が $4.8 \%$ から $6.7 \%$ へと増加して いた（表 1 ）。

性別分布は男性1075例 (92.7\%)，女性85例 (7.3\%) であった。女性喉頭癌患者は，前期 43 例 $(7.6 \%)$, 後期 42 例 $(7.1 \%)$ と顕著な増減は みられなかった。また，非喫煙者は42例 (3.6\%) に過ぎず，喉頭癌患者の $96.4 \%$ は喫煙者（中途 禁煙者を含む)であった。非喫煙喉頭癌患者は, 前期 18 例 $(3.2 \%$ ） 加後期 24 例 $(4.0 \%)$ へと 症例数, 比率ともにわずかに増加していたが, 統計学的有意差はみられなかった（ $p=0.52 ） 。$

発癌部位別の分布は, 声門癌746例, 声門上癌 393例 (うち混合型116例), 声門下癌14例, 多中 心性発癌 7 例であった。声門癌が前期の356例 (62.8\%) から後期の390例（65.8\%）へと症例 数, 比率ともに増加し, 声門上癌が200例 (35.3 \%) から 193例 $(32.5 \%)$ へと症例数，比率とも 


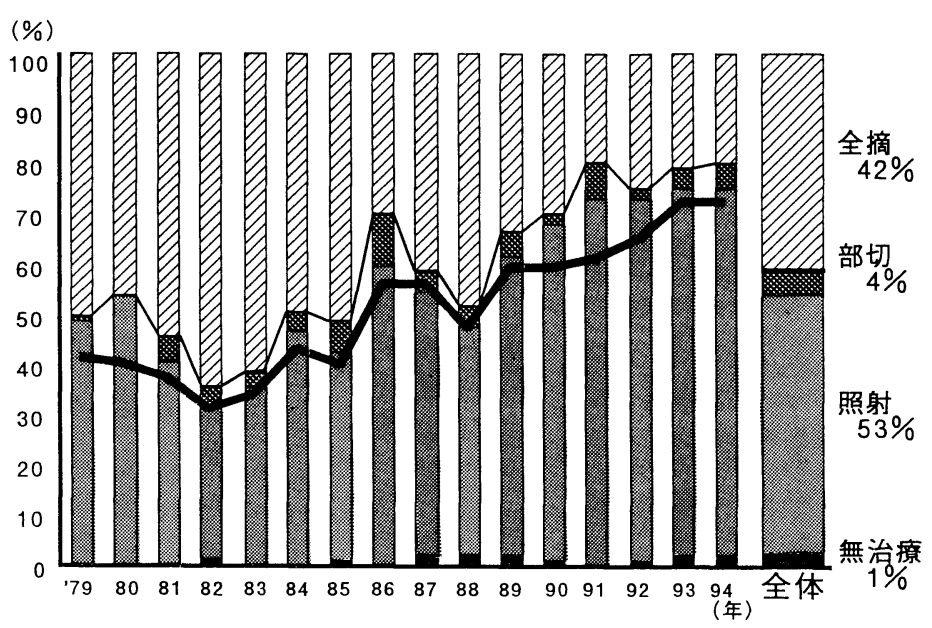

図 1 初回治療と喉頭温存率の推移 $(1979 \sim 94, \mathrm{n}=1160)$

太折線：喉頭温存率の推移, 細折線：照射と部分切除術の比率の推移。

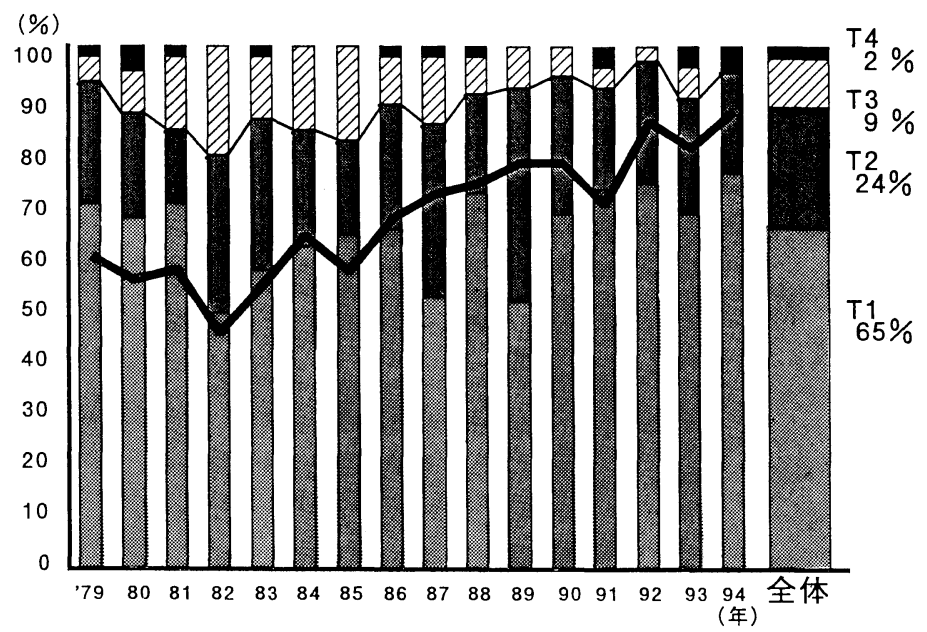

図 2 T病期と喉頭温存率の推移（声門癌， $\mathrm{n}=746$ )

太折線：喉頭温存率の推移, 細折線 : $\mathrm{T} 1 ・ \mathrm{~T} 2$ 症例の比率の推移。

に減少していた。また，声門上癌のうち混合型 は，前期56例 $(9.9 \%)$ と後期60例 $(10.1 \%)$ の 間で増減はみられなかった（表 2 )。

\section{2. 初回治療および喉頭温存率の推移(図 1)}

初回治療のうち, 喉頭全摘の占める比率は全 体では42\%であった。1985年以前は50\%以上で あったが減少傾向を示し，1991年以降は30\%以 下となっていた。いっぽう根治照射の比率は全 体では53\%であったが，逆に増加傾向を示し， 1986年以降は $50 \%$ 以上，1990年以上は60\%以上 を占めるようになってきていた。また，喉頭部
分切除は全体の $4 \%$ に過ぎず，特に増加の傾向 はみられなかった。

喉頭温存率は漸増し，1985年以前は40\%前後 であったが，1986年以降は50\%以上，1991年以 降は60\%以上，1993年以降は70\%以上となって いた。前期の喉頭温存率の平均は $40 \%(226 / 563)$ であったが，後期では平均 $61 \%(354 / 583)$ と有 意に向上がみられた $(p<0.0001)$ 。

1 ）声門癌のT病期 (UICC，1987年）および 喉頭温存率の推移

声門癌746例の T病期分布は, T1，484例 65 
日気食会報, 48（6), 1997

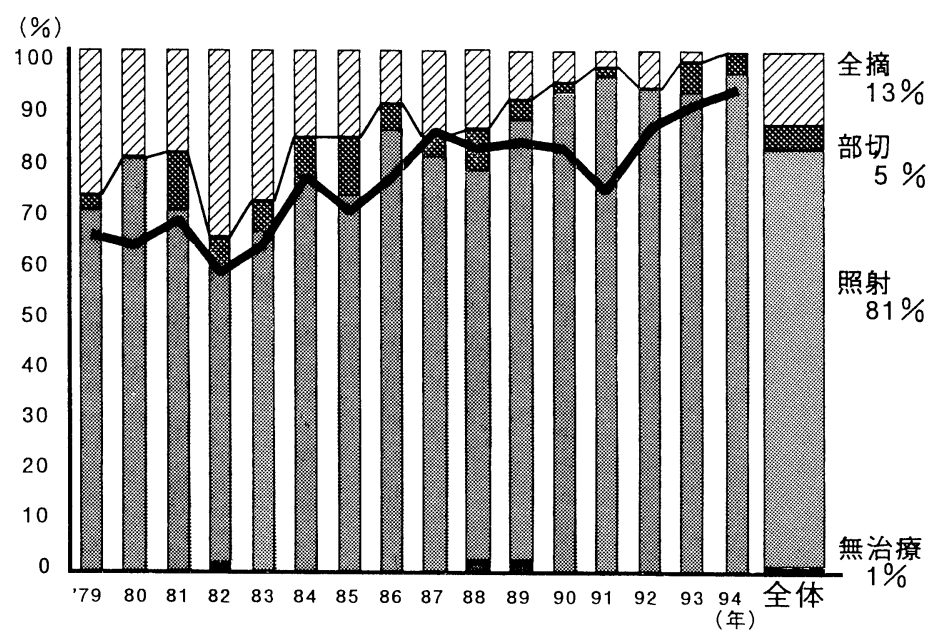

図 3 初回治療と喉頭温存率の推移（声門癌 $\mathrm{T} 1 \cdot \mathrm{T} 2, \mathrm{n}=663$ )

太折線：喉頭温存率の推移, 細折線 : 照射と部分切除術の比率の推移。

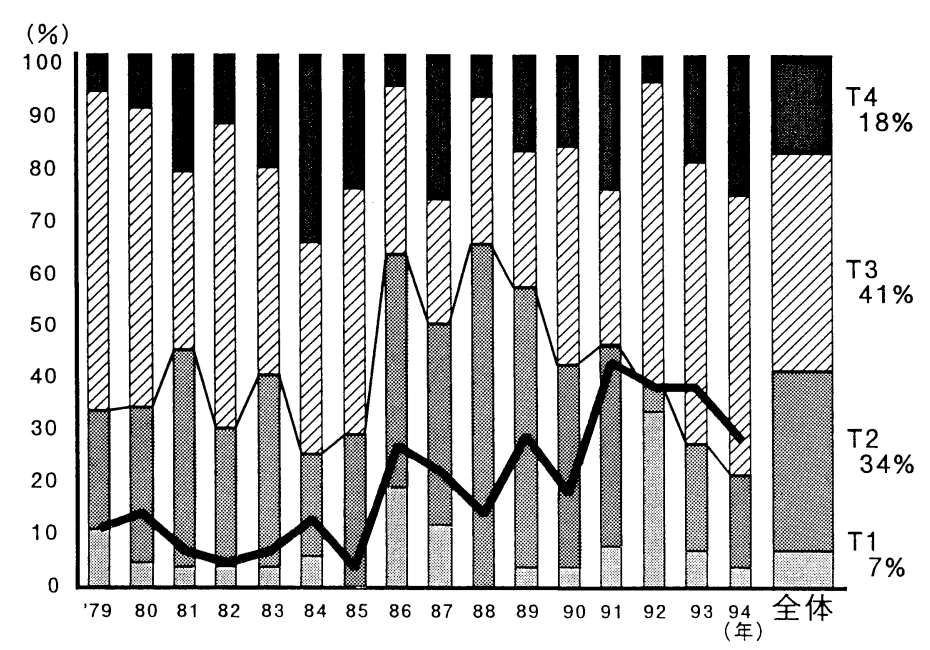

図 $4 \mathrm{~T}$ 病期と喉頭温存率の推移（声門上癌, $\mathrm{n}=393$ )

太折線：喉頭温存率の推移, 細折線 : $\mathrm{T} 1 \cdot \mathrm{T} 2$ 症例の比率の推移。

\%); T2, 179例 (24\%)； T3，68例( $9 \%)$; T4, 15例（2\%）であった。

喉頭温存が積極的に考慮される $\mathrm{T} 1$ ・ T2 症例 の占める比率は，前期の平均 $85 \%(304 / 356)$ か ら後期では平均 $92 \%(359 / 390)$ へと $7 \%$ の増加 であった（ $p=0.0079 ）$ 。喉頭温存率は上昇傾向 を示し，前期の $58 \%(205 / 355)$ から後期では78 \%（303/387）へと20\%の増加であった（ $p<$ 0.0001 ) (図 2 )。

また，T1・T2 症例663例に対する初回治療法 の推移をみると, 部分切除術の比率に変化はみ
られなかったが，喉頭全摘が漸減し，根治照射 の比率が増加傾向を示した。喉頭温存率も年及 向上し, 前期と後期を比較すると, 平均 $68 \%$ (205/303）から85\%(302/357）へと17\%の増加 が認められた $(p<0.0001)$ (図 3 )。

2 ）声門上癌の T病期 (UICC，1987年）およ び喉頭温存率の推移

声門上癌393例の T 病期分布は, T1, 26例 ( 7 \%) ; T2, 135例 (34\%); T3, 161例 (41\%); T4，71例（18\%）であった。

$\mathrm{T} 1$ • $\mathrm{T} 2$ 症例の占める比率は, 前期の平均 $36 \%$ 


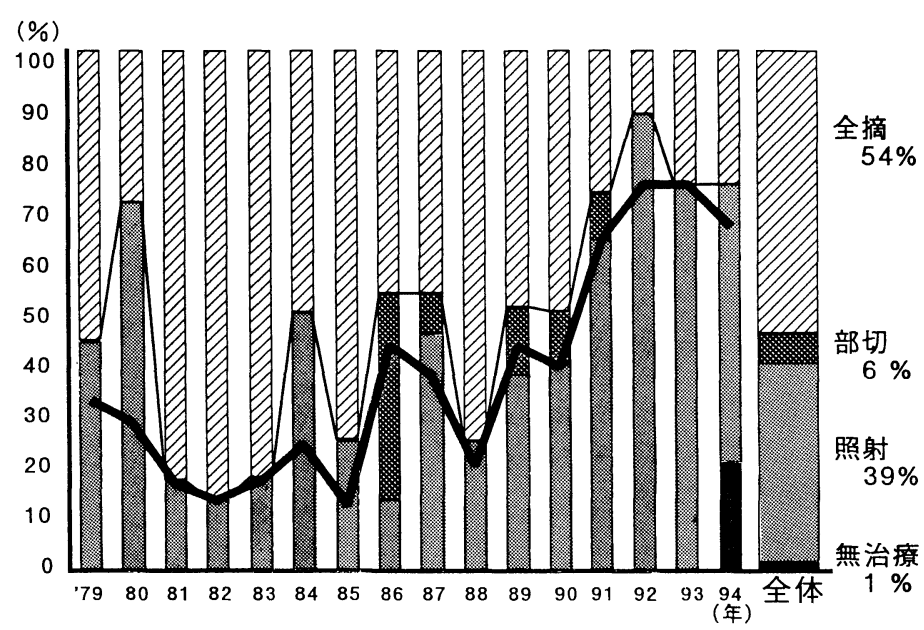

図 5 初回治療法と喉頭温存率の推移（声門上癌 $\mathrm{T} 1 \cdot \mathrm{T} 2, \mathrm{n}=161$ ) 太折線：喉頭温存率の推移, 細折線 : 照射と部分切除術の比率の推移。

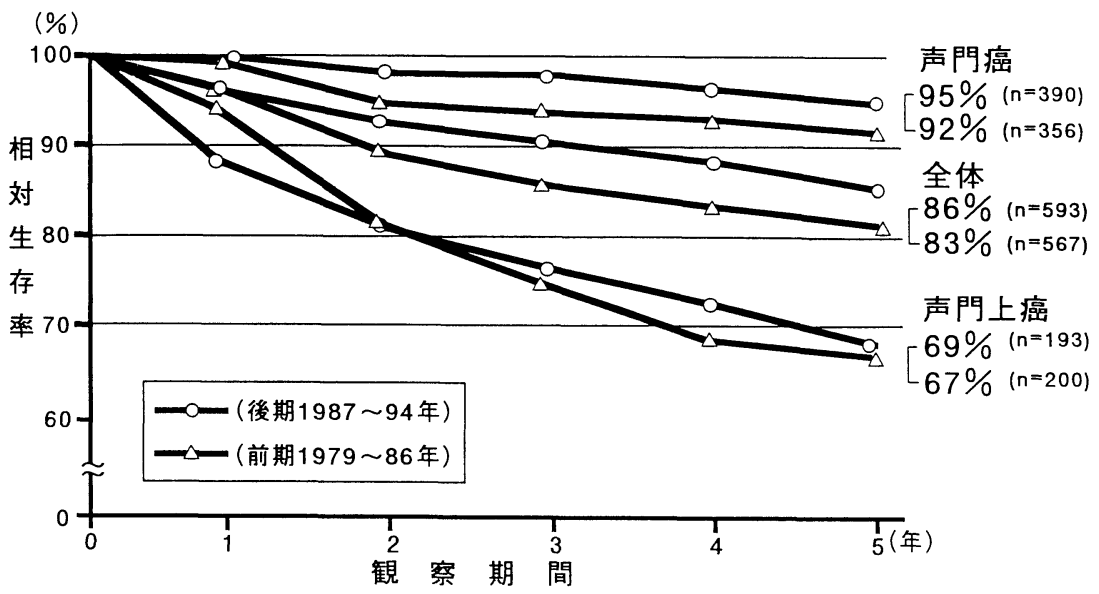

図 6 喉頭癌の治療成績の年代別比較

（71/200）から後期では平均47\%（90/193）へと

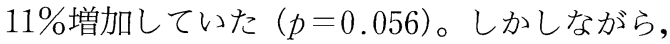
1988年以降はむしろ減少傾向がみられた。喉頭 温存率は，前期の10\%（20/197）から後期では 27\%（50/183）へと17\%増加していた（pく 0.0001)（図 4 )。

また，T1・T2 症例161例に対する初回治療法 の推移をみると，喉頭全摘が漸減し，根治照射 の比率が増加傾向を示していた。喉頭温存率も 上昇傾向を示し，前期と後期を比較すると， 24 \% (17/71) から $44 \%(39 / 89)$ へと20\%の増加 が認められた（ $p=0.014 ）$ (図5)。

\section{3．治療成績の推移（図 6 )}

前期と後期の治療成績について，5 年相対生 存率で比較すると, 喉頭癌全体では $83 \%$ から 86 \%へ，声門癌では $92 \%$ から $95 \%$ ，声門上癌で も $67 \%$ から $69 \%$ へわずかながら向上がみられ たが,これら各 2 群間に有意差はみられなかっ た。

\section{IV. 考 察}

喉頭癌の臨床面からみた記述疫学の推移の特 徵について, 佐藤(5) は, 高齢化現象と欧米化現象 をあげている。高齢化現象とは, 喉頭癌の罹患 
年齢が1980年代前半まで高齢化の一途をたどっ てきていることをさしている。また，発癌部位 について，以前は声門上癌が過半数を占めてい たが，1970年以降，声門癌が過半数を占めるよ うになり，欧米型のパターンと等しくなったこ とを喉頭癌の欧米化現象と名付けた。

1979年から1994年の16年間の罹患年齢の分布 は，60歳代が全体の35\%を占め，次いで50歳代 と70歳代がおのおの 20 数\%を，さらに50歳未満 と80歳以上がおのおの数\%を占めるという形に なっていた。この分布の形は, 前期と後期の間 に変わりはなく，また，平均年齢もともに64歳 であったことから，扔拉むね高齢化現象はプラ トーに達したかのようにみえる。しかしながら， 進行癌になるまでにまだ何年か要するであろう と考えられる早期癌の占める割合が増加してい ることを考慮すると, 前期と後期の間に年齢分 布の差がないということは，むしろ高齢化現象 は潜在的にゆるやかながら進行しているのでは ないかと考えられる。

発癌部位の推移では, 声門癌が症例数, 比率 ともに増加し，いっぽう声門上癌は比率のみな らず，症例数自体も減少していた。喉頭癌の欧 米化現象も，ゆるやかながら進行していると考 えられた。また, 声門上癌のうちの混合型は, 症例数, 比率ともに横這いであったことより, 混合型を除く狭義の声門上癌の症例数の減少 が, 推移の特徵のひとつであった。

喉頭癌の 5 年相対生存率は $90 \%$ に近く，他の 部位の癌に比べて, 予後のよい癌の一つであ る6)。したがって, 根治性を犠牲にしない機能温 存治療が以前にも増して求められるようになっ

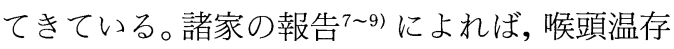
率 (喉頭全摘非施行率) は，お抢むね 50 ～70\% であった。当科での喉頭癌全体の喉頭温存率は, 1985年以前は $40 \%$ 前後であったが，上昇傾向を 示し，1993年以降は70\%以上となっていた。経 過観察期間が 2 年末満の生存例は71例（6\%） のみであり, 今後の再発による喉頭温存率の低 下はわずかであると考えられる。前期の喉頭温 存率は平均 $40 \%$ であったが, 後期では平均 $61 \%$ と有意に向上がみられた。また，5年相対生存 率も $83 \%$ から $86 \%$ へと有意差はないながらも上 昇し, 根治性を損なうことなく機能温存治療が
可能となっていた。これらが可能となってきた 背景には, 早期癌の増加と診断・治療方法の進 歩が考えられる。

声門癌では, 早期より嗄声が出現することか ら，喉頭温存が積極的に考慮される $\mathrm{T} 1 ・ \mathrm{~T} 2$ 症 例の占める比率は以前から高かったが，前期の 平均 $85 \%$ から後期では $92 \%$ へさらに $7 \%$ の増 加がみられた。社会に対する啓発活動の成果と して，嗄声を自覚した患者の早期受診が進んた 結果ではないかと考えられる。早期癌症例の増 加に伴う喉頭温存率の向上は当然であるが，喉 頭温存率は前期 $58 \%$ から後期 $78 \%$ へとより以上 の増加がみられた。その理由のひとつは $\mathrm{T} 1 ・ \mathrm{~T} 2$ 症例の喉頭温存率の向上であり，前期の $68 \%$ か ら後期の $85 \%$ へと $17 \%$ の増加が認められた。こ の背景には放射線治療方法の工夫による制御率 の向上や，照射後再発例に対する部分切除術の 適応の拡大などが考えられる。当センター放射 線治療科では，1986年以降ルーチンに頭部固定 用のシェルとウェッジフィルターを用いている が, 茶谷ら ${ }^{10)}$ はこれらの使用による局所制御率 の向上を報告している。また, 数年前より, 照 射前の喉頭 VTR 記録をルーチンに行っている が,これにより照射後再発時に, 照射前の状態 をより正確に把握できるようになったことが， 部分切除術の適応拡大につながっているような 印象を持っている。

声門上癌では, 早期に自覚症状が出にくいた め, $\mathrm{T} 1 \cdot \mathrm{T} 2$ 症例の占める比率は声門癌に比べて 低いものの, 前期の平均 $36 \%$ から後期の $47 \%$ 一 と $11 \%$ の増加がみられた。1988年以降は減少傾 向がみられたが,これは CT 検査(スライス幅： $3 \sim 5 \mathrm{~mm}$ ) をルーチン化し, preepiglottic space への深部浸潤がより正確に診断されるよ うになった結果，T3 が増加したためではない かと考えている。喉頭温存率は, 前期では $10 \%$ に過ぎなかったが，後期では $27 \%$ と $17 \%$ の増 加を認めた。声門癌同様, $\mathrm{T} 1 \cdot \mathrm{T} 2$ 症例の喉頭温 存率の向上（前期 $24 \%$ から後期 $44 \%$ へと $20 \%$ の 増加）が，その理由のひとつであった。CT 検査 による深部浸潤の正確な把握が, 放射線治療お よび部分切除術による喉頭温存治療法の的確な 選択につながっていると考えられた。 


\section{V.まとめ}

1979年から1994年までの16年間の喉頭癌一次 例1160例を対象として，喉頭癌の臨床面からみ た記述疫学および喉頭温存率に関して，前期 （1979～86年） 567例と後期（1987～94年） 593例 に分けて比較し検討した。

1 ）罹患年齢の分布は22～91歳（平均64歳） で，60歳代が全体の35\%を占めており，これら は前期と後期の間で差はみられなかった。早期 癌の占める割合が増加していることを考慮する と, 高齢化現象は潜在的にゆるやかながら進行 しているのではないかと考えられた。

2 ) 発癌部位の推移は, 前期に比べ後期では, 声門癌が症例数, 比率ともに増加し，いっぽう 声門上癌は比率のみならず，症例数自体も減少 していた。喉頭癌の欧米化現象は，ゆるやかな がら進行していると考えられた。

3 ) 声門癌では, T1・T2 症例の占める比率が $7 \%$ 増加していたが，喉頭温存率は前期 $58 \%$ か ら後期 $78 \%$ へ $20 \%$ の増加であった。特に, $\mathrm{T} 1 \cdot \mathrm{T} 2$ 症例の喉頭温存率は, 前期の $68 \%$ から後 期の $85 \%$ へと $17 \%$ の増加を認めた。すなわち, 早期癌が増えただけではなく, 声門癌の約 $90 \%$ を占める $\mathrm{T} 1$ ・T2 症例に対する診断および治療 方法の進歩が，声門癌全体の喉頭温存率を向上 させていたものと考えられた。

4 ）声門上癌では, T1・T2 症例の占める比率 が11\%増加していたが，喉頭温存率は前期 $10 \%$
から後期 $27 \%$ へ $17 \%$ の増加であった。特に， $\mathrm{T} 1$ ・ T2 症例の喉頭温存率は, 前期 $24 \%$ から後期 44\%へと20\%の増加を認めた。CT 検査による 深部浸潤の正確な把握が, 放射線治療および部 分切除術の的確な選択につながつた結果と考え られた。

\section{文献}

1) 藤本伊三郎, 花井 彩, 津熊秀明 - 他：大阪府 における癌の罹患と死亡 (1963-1989)。pp.105$107 ;$ pp.111-113, 篠原出版, 東京, 1993.

2 ) 小野勇：疫学的にみた喉頭癌の動向. JOHNS, 4:1171-1174, 1988.

3 ) 藤巻龍枝：喉頭癌の臨床統計的観察一全国医療 機関登録患者の生存率調查 (昭和 $35-44$ 年)。 耳鼻, $76: 533-577,1973$.

4) 谷内山仁, 納谷 裕：当教室における喉頭癌の 臨床統計。耳鼻臨床, 補38：53-62, 1990.

5 ) 佐藤武男：喉頭癌一その基礎と臨床一（改訂 版), pp.17-29, 金原出版, 東京, 1986.

6 ）佐藤武男：がんはここまで治る.耳展，40：1018, 1997.

7 ）樋口栄作, 飯塚桂司, 庄田英明 - 他：当科に押 ける喉頭癌の臨床的検討. 日耳鼻, $99: 385-394$, 1996.

8 ）五十嵐文雄, 野々村直文, 中野雄一：当教室に おける喉頭癌症例の検討. 日耳鼻, $93: 772-778$, 1990.

9) 太田行紀，平川勝洋，夜陣紘治・他：喉頭癌の 臨床統計一当教室 15 年間の検討一. 耳鼻臨床, 補72：21-30, 1994.

10) Chatani, M., Matayoshi, Y., Masaki, N., et al. : Radiation therapy for early glottic carcinoma : Indication for the wedge filter. Strahlenther. Onkol., 169 : 655-659, 1993. 